\title{
Microstructural Changes of Al-Cu Alloys After Prolonged Annealing at Elevated Temperature
}

\author{
Małgorzata Wierzbińska and Jan Sieniawski \\ Rzeszow University of Technology, Rzeszow, \\ Poland
}

\section{Introduction}

The precipitation-strengthened 2xxx series $\mathrm{Al}-\mathrm{Cu}$ alloys are one of the most important high-strength aluminium alloys. They have been employed extensively in the aircraft and military industries, in which materials are frequently subjected to elevated temperature. The aluminium casting alloys, based on the $\mathrm{Al}-\mathrm{Cu}$ system are widely used in light-weight constructions and transport applications requiring a combination of high strength and ductility.

$\mathrm{Al}-\mathrm{Cu}$ alloys are less frequently used than $\mathrm{Al}-\mathrm{Si}-\mathrm{Cu}$ grades due to technological problems in production process (e.g. high propensity to microcracking during casting). However they are the basis for development of multicomponent alloys. Typical alloys for elevated temperature application are $\mathrm{Al}-\mathrm{Cu}-\mathrm{Ni}-\mathrm{Mg}$ alloys (containing about $4,5 \% \mathrm{Cu}, 2 \% \mathrm{Mg}$ and $2 \% \mathrm{Ni}$ ). Their good properties at elevated temperature result from formation of intermetallic phases $\mathrm{Al}_{6} \mathrm{Cu}_{3} \mathrm{Ni}$ and $\mathrm{Al}_{2} \mathrm{CuMg}$, both during crystallization and precipitation hardening (El-Magd \& Dünnwald, 1996; Martin, 1968; Mrówka-Nowotnik et al., 2007).

Mechanism of precipitation hardening in cast and wrought binary $\mathrm{Al}-\mathrm{Cu}$ alloys is well known and widely covered in literature. There are some suggestions that decomposition of supersaturated $\alpha(\mathrm{Al})$ solid solution in other precipitation hardened alloys like $\mathrm{Al}-\mathrm{Cu}-\mathrm{Mg}$, $\mathrm{Al}-\mathrm{Si}-\mathrm{Cu}, \mathrm{Al}-\mathrm{Mg}-\mathrm{Si}$ follows the same route as in the $\mathrm{Al}-\mathrm{Cu}$ alloys with some specific features of the particular stages of the process (Martin, 1968;). The interest in course and kinetics of the aging process has the practical meaning as the early stages of aging leads to significant improvement of mechanical properties of the alloys. Maximum hardening effect in $\mathrm{Al}-\mathrm{Cu}$ alloy is a result of in situ transformation of GP zones into transient phase $\theta$ ". Increase in aging temperature leads to decrease of the hardness of solid solution $\alpha(\mathrm{Al})$ due to precipitation of equilibrium $\theta$ phase on the grain boundaries or on the $\theta^{\prime} /$ matrix phase boundaries. Prolonged aging may lead to microstructure degradation related to coagulation and/or coalescence of the highly dispersed hardening phase precipitates resulting in decrease of hardening effect (Mrówka-Nowotnik et al., 2007; Wierzbińska \& Sieniawski, 2010). Therefore development of the chemical composition of the alloy, especially intended for long term operation at elevated temperature, requires taking into account factors resulting in deceleration of the coagulation process and obtaining stable microstructure consisting of solid solution $\alpha$ grains and highly dispersed precipitates of the second phase (Wierzbińska \& Sieniawski, 2010). 


\section{Material and methodology}

The investigation was performed on the two casting alumium alloys AlCu4Ni2Mg and AlCu6Ni. AlCu4Ni2Mg is the standard alloy used currently for highly stressed structural elements of engines and $\mathrm{AlCu} 6 \mathrm{Ni1}$ is an experimental alloy that was chosen to investigate the influence of the increased content of $\mathrm{Cu}$ on the phase composition, microstructure morphology and mechanical, technological and operational properties. The alloys were cast into metal moulds and subjected to X-ray inspection in order to exclude the presence of porosity or oxide films.

The alloys were subjected to heat treatment T6 followed by annealing at $523 \mathrm{~K}$ and $573 \mathrm{~K}$ for 150 and 500 hours. After analysis of the results of preliminary tests it was found, that it is advisable to apply additional annealing times at particular temperature, i.e. 100, 300 and 750 hours.

Heat treatment conditions were established on the basis of the phase equilibrium diagrams Al-Si and Al-Cu and available heat treatment data for the alloys with similar chemical composition (both from literature and used in industry practice). The consideration was also given to requirements concerning mechanical properties of the alloys resulting from operation condition of the structural elements made of these alloys. The chemical composition of the investigated alloys and heat treatment parameters are presented in table 1.

\begin{tabular}{|c|c|c|}
\hline \multirow{2}{*}{ Element } & \multicolumn{2}{|c|}{ Element content, wt. \% } \\
\cline { 2 - 3 } & AlCu4Ni2Mg & AlCu6Ni \\
\hline $\mathrm{Mn}$ & $<0.10$ & 0.90 \\
$\mathrm{Ni}$ & 2.10 & 1.10 \\
$\mathrm{Cu}$ & 4.30 & 6.36 \\
$\mathrm{Zr}$ & - & 0.01 \\
$\mathrm{Fe}$ & 0.10 & 0.20 \\
$\mathrm{Si}$ & 0.10 & 0.10 \\
$\mathrm{Mg}$ & 1.50 & 0.05 \\
$\mathrm{Zn}$ & 0.30 & - \\
$\mathrm{Al}$ & balance & balance \\
\hline solution treatment & $793^{ \pm} \mathrm{K} / 5 \mathrm{~h} /$ & $818^{ \pm} 5 \mathrm{~K} / 10 \mathrm{~h} /$ \\
& water cooling & water cooling \\
\hline artificial ageing & $523^{ \pm} \mathrm{K} / 5 \mathrm{~h} /$ & $498^{ \pm} \mathrm{K} / 8 \mathrm{~h} /$ \\
& air cooling & air cooling \\
\hline
\end{tabular}

Table 1. Composition of $\mathrm{AlCu} 4 \mathrm{Ni} 2 \mathrm{Mg}$ and $\mathrm{AlCu} 6 \mathrm{Ni}$ alloys and heat treatment parameters

Examination of the alloys microstructure was carried out using light microscope (LM), as well as scanning (SEM) and transmission (TEM) electron microscopes. 


\section{Results and discussion}

Figs. 1 to 4 show the results of microscopic observations of $\mathrm{AlCu} 4 \mathrm{Ni} 2 \mathrm{Mg}$ and $\mathrm{AlCu} 6 \mathrm{Ni}$ alloys (in T6 condition). In both of investigated alloys large, irregular shaped precipitates of
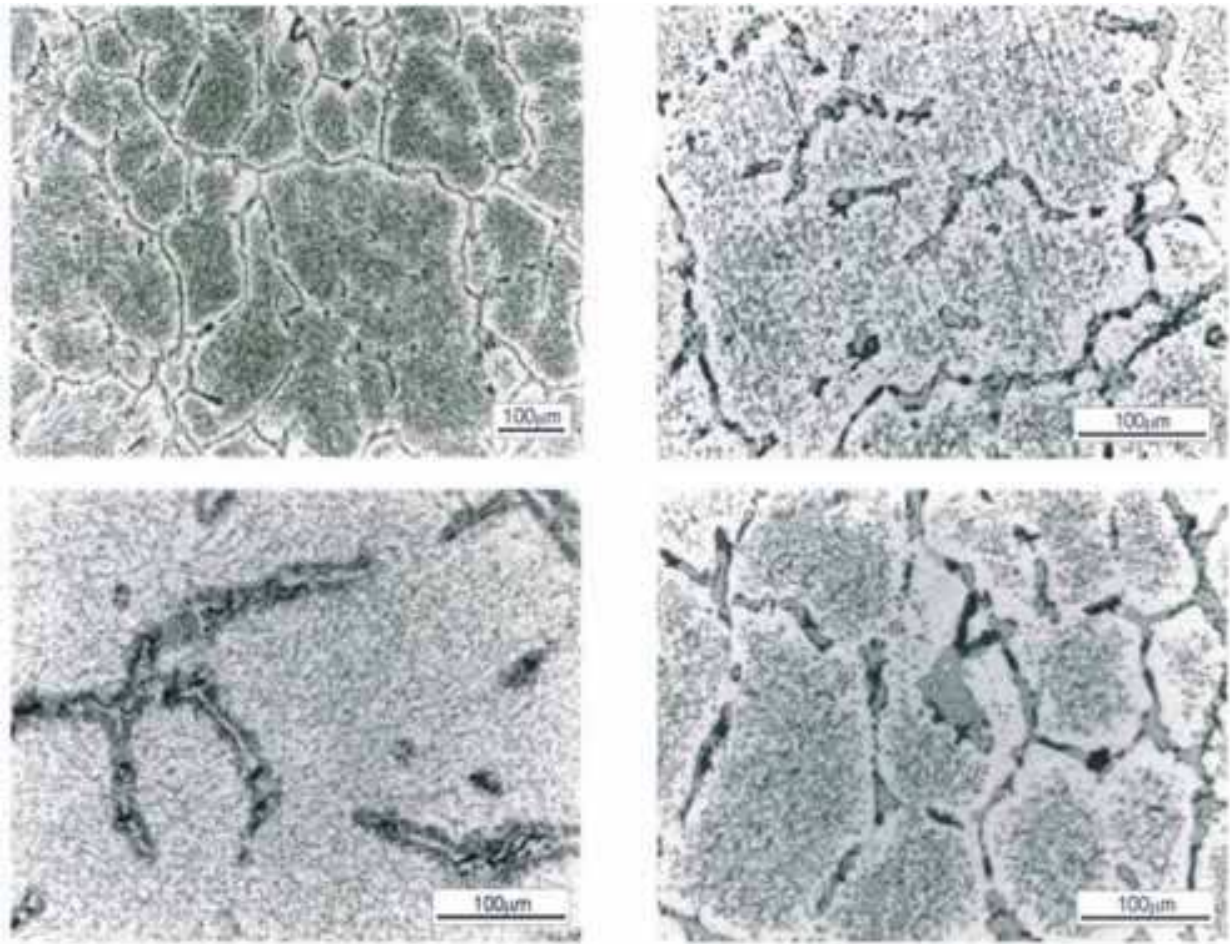

Fig. 1. Microstructure of AlCu4Ni2Mg alloy in T6 condition (LM)
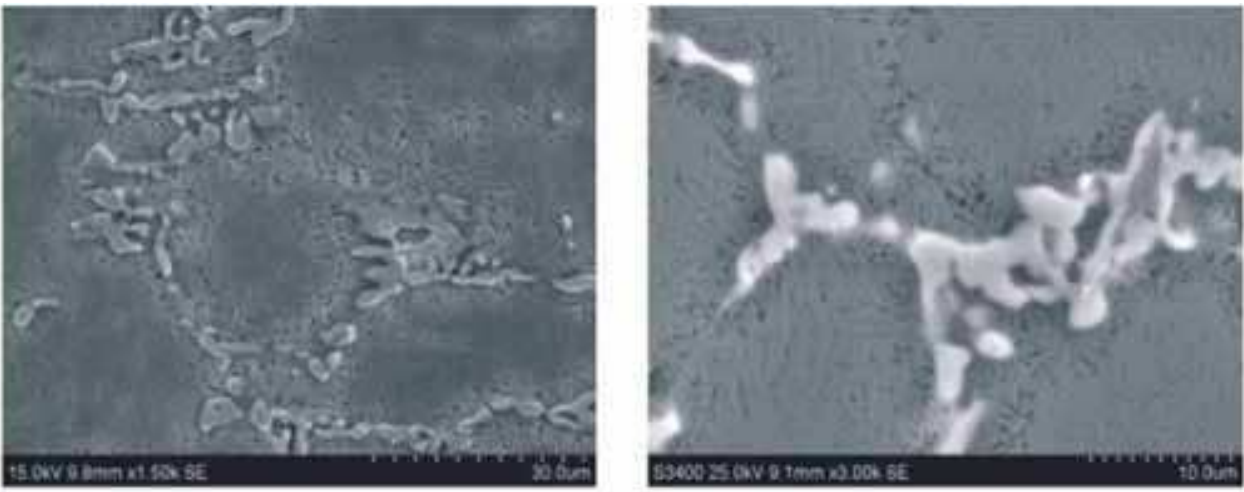

Fig. 2. Microstructure of $\mathrm{AlCu} 4 \mathrm{Ni} 2 \mathrm{Mg}$ alloy in $\mathrm{T} 6$ condition: precipitations of intermetallic phases in interdendritic areas (SEM) 
intermetallic phases, located on the dendrite boundaries of solid solution $\alpha$-Al and dispersive, spheroidal and strip shaped hardening phase precipitates homogenously distributed throughout the solid solution were observed.
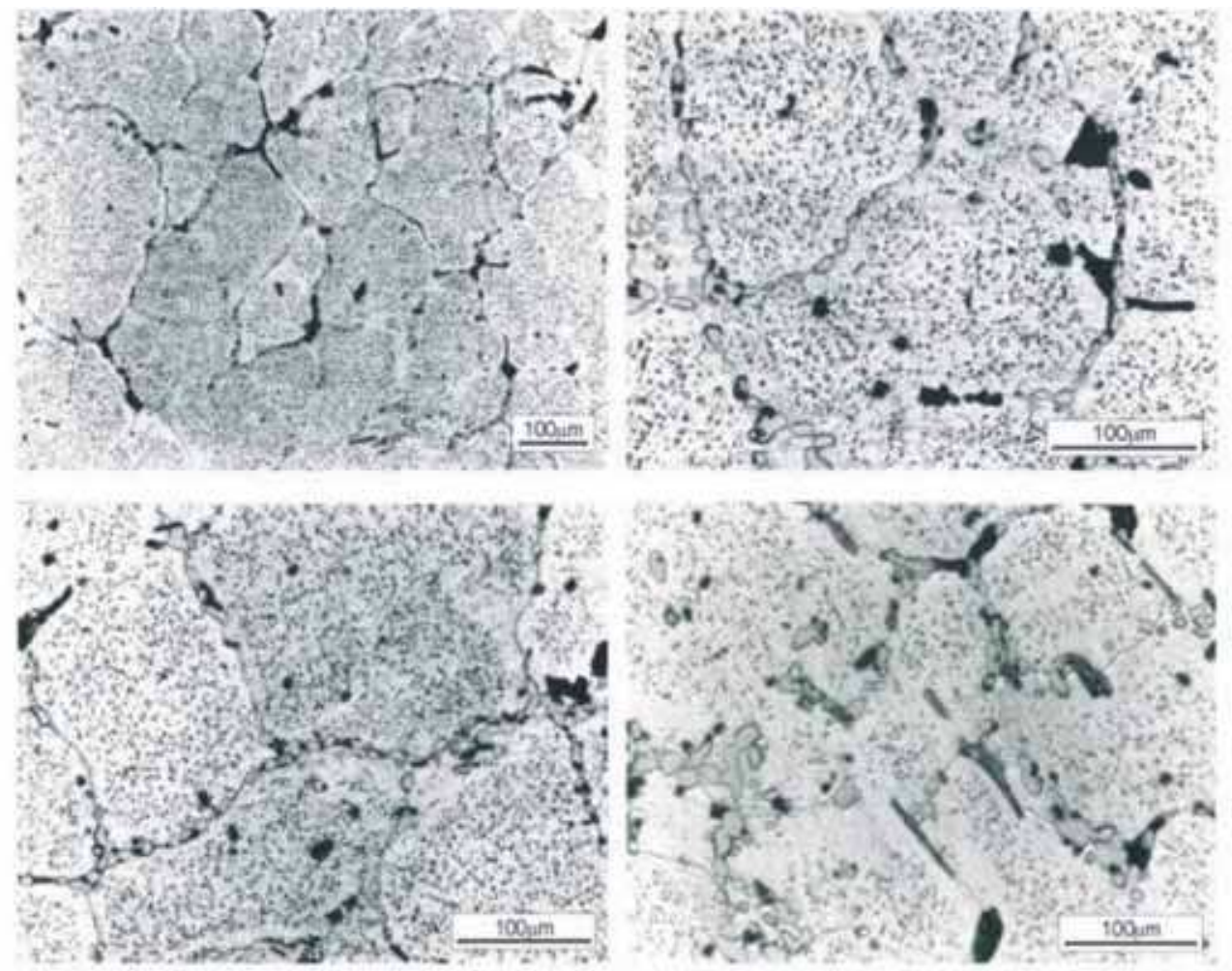

Fig. 3. Microstructure of the AlCu6Ni alloy in T6 condition (LM)
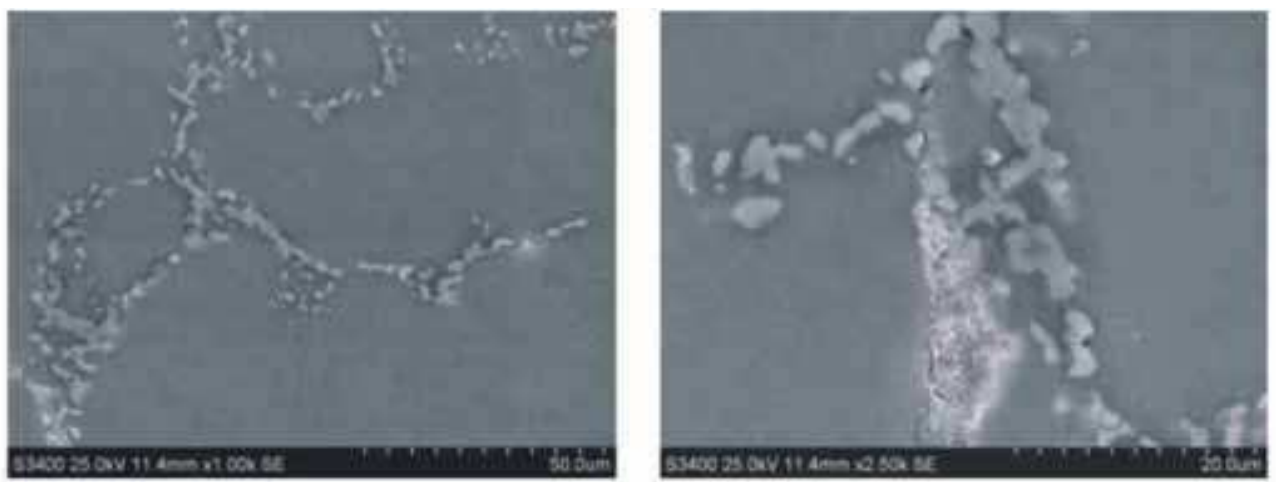

Fig. 4. Microstructure of the AlCu6Ni1 alloy in T6 condition (SEM) 
Based upon the EDS results the phases forming large size particles was identified as Al-CuNi, Al-Cu-Ni-Fe and Al-Cu-Mn (fig. 5-6) (Mrówka-Nowotnik et al. 2007, Wierzbińska \& Sieniawski 2010).
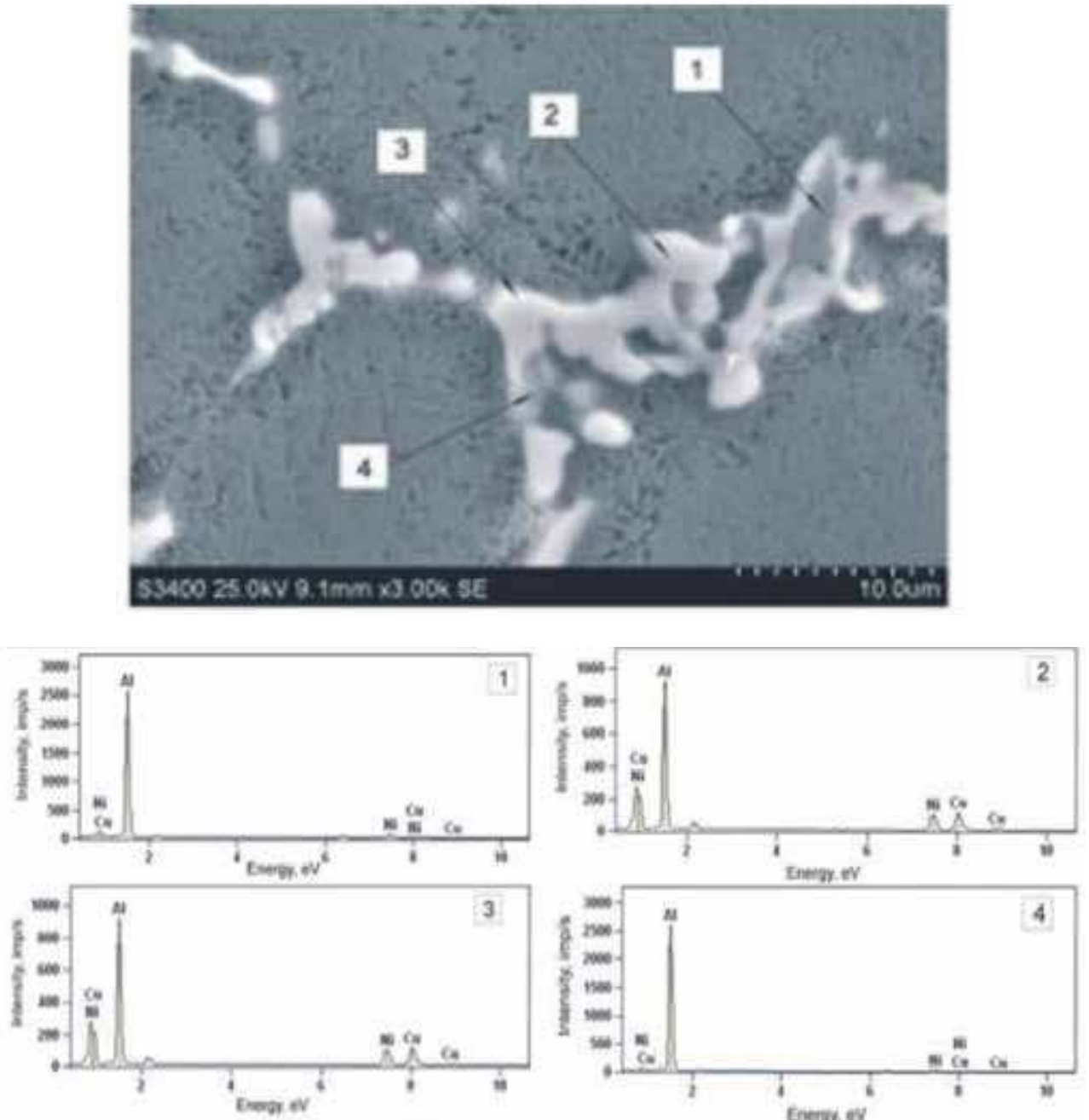

Element coutent, wt:

\begin{tabular}{|c|c|c|c|c|}
\hline & AlK & Fer: & MAR & CER \\
\hline AlCiFNAMg-pt 2 & 76,32 & 5,95 & 1399 & 4,35 \\
\hline AlCanesig-pD & 47,26 & & 2327 & 29,48 \\
\hline AlCLANOMg-ptS & 5405 & & 2314 & 22,91 \\
\hline AlCLANDM(g-p<-4 & 85,92 & 3,18 & 9,06 & 2,49 \\
\hline
\end{tabular}

Fig. 5. AlCu4Ni2Mg alloy - EDS analysis of the areas 1-4 

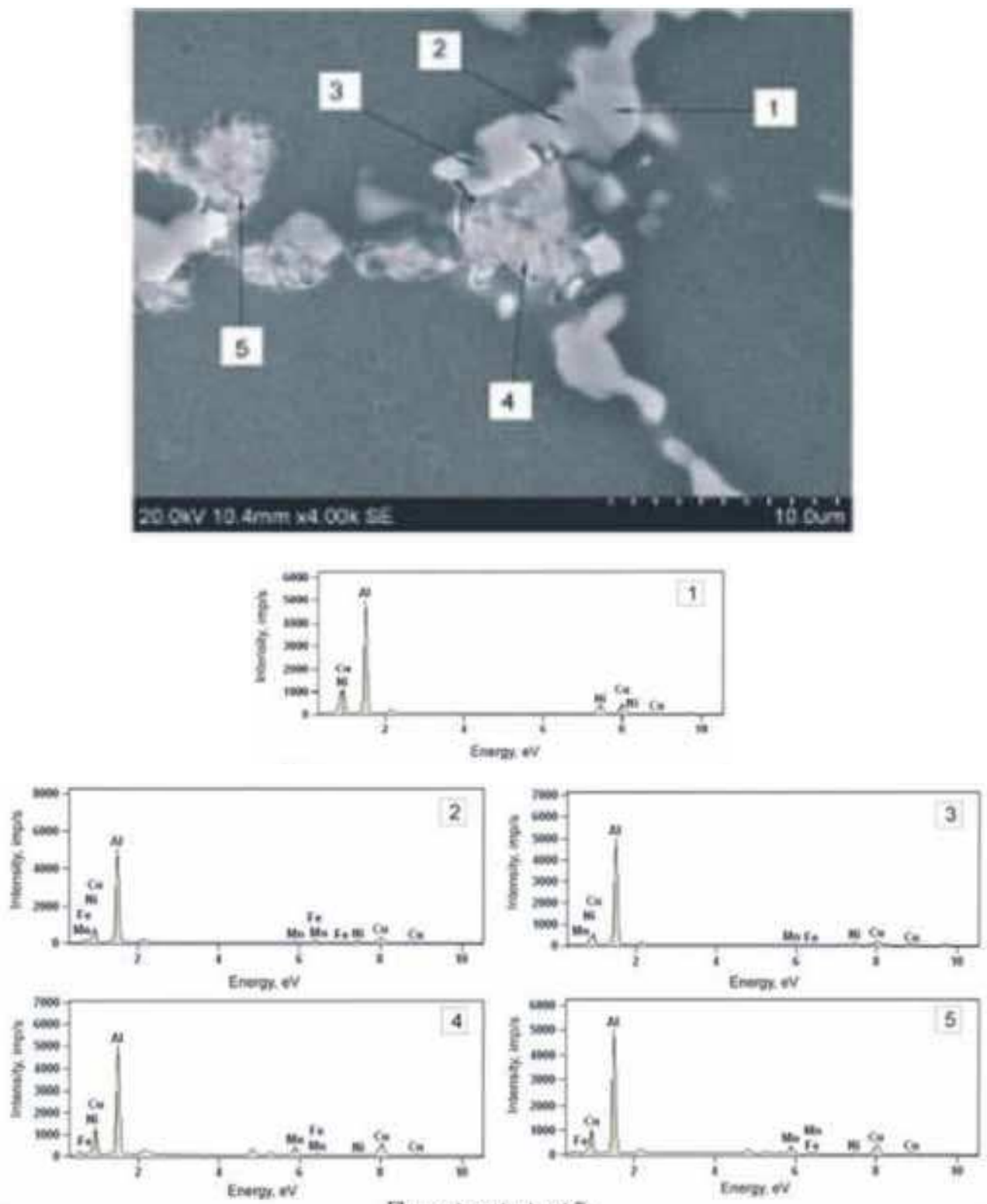

Flement content, wt.

\begin{tabular}{|c|c|c|c|c|c|}
\hline & $A B-X$ & $M / x-R$ & $F \in K$ & WFR & C. $=R$ \\
\hline AlCuENit-pt 1 & 53,00 & & & 19,43 & 2051 \\
\hline Atciennt-pe 2 & $60, \infty$ & 230 & 4,65 & 6,68 & 2629 \\
\hline AlCuENeI- $P 3$ & 65,90 & 3,94 & 129 & 844 & 20,43 \\
\hline AtCiGNi1-pe 1 & 51,16 & 10,42 & 1.19 & 224 & 35,02 \\
\hline AlC $6 \mathrm{Nit}-\mathrm{pl}^{5}$ & 55,12 & 10,06 & 1,0 & 219 & 3076 \\
\hline
\end{tabular}

Fig. 6. AlCu6Ni alloy - EDS analysis of the areas 1-5 

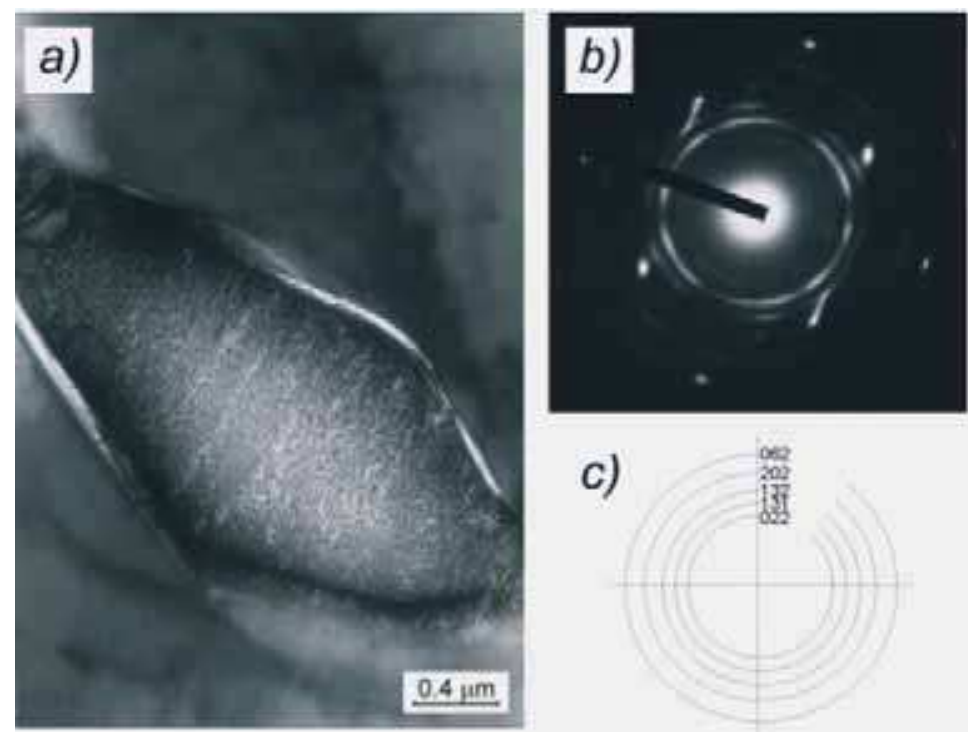

c) $=\frac{\log }{125}$

\begin{tabular}{l|l|l|l|l|l}
$n k 1$ & 002 & 131 & 132 & 202 & 062 \\
\hline$d(\mathrm{~nm})$ & 28,73 & 23,50 & 20,24 & 17,34 & 14,12 \\
\hline$d(\mathrm{~nm})$ & 28,29 & 13,13 & 20,18 & 17,49 & 14,16 \\
$S_{-A 1} \mathrm{CuMg}_{2}$ & & & & &
\end{tabular}

Fig. 7. Microstructure of the $\mathrm{AlCu} 4 \mathrm{Ni} 2 \mathrm{Mg}$ alloy: a) precipitates of $S-\mathrm{Al}_{2} \mathrm{CuMg}$ phase, b) electron diffraction pattern obtained from the precipitate, c) solution of the diffraction pattern
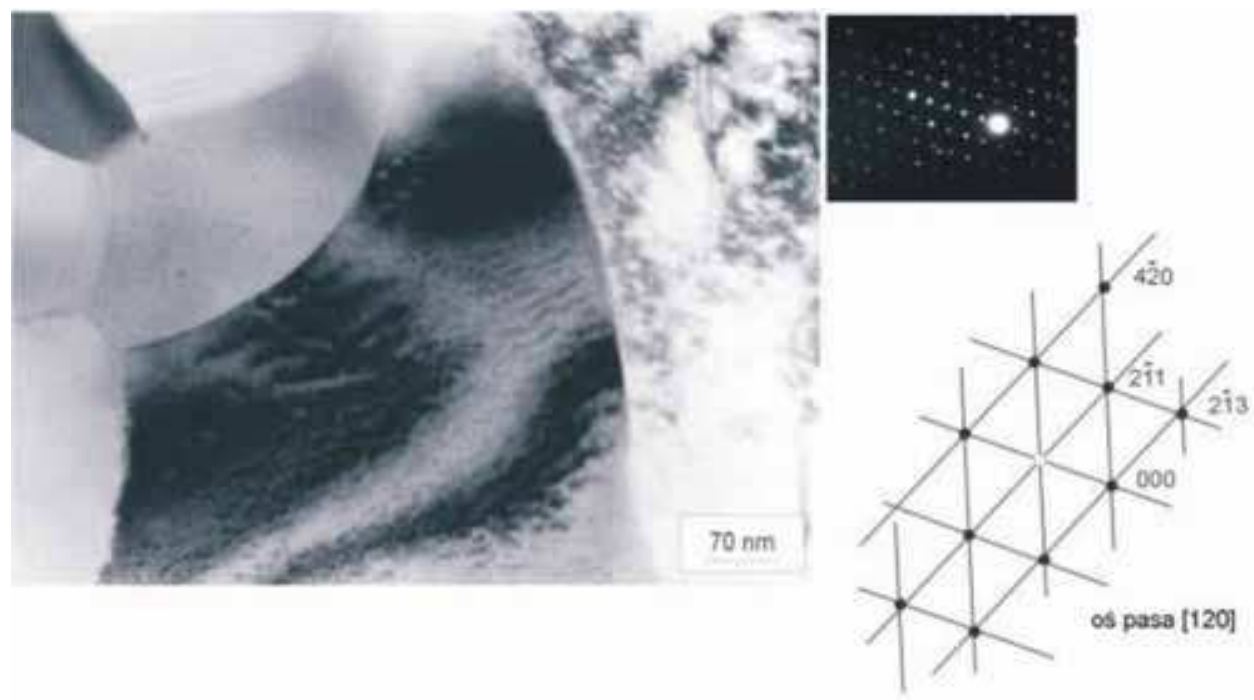

Fig. 8. Microstructure of the AlCu6Ni alloy: particle of $\alpha-\mathrm{Al}_{2} \mathrm{CuMg}$ phase 
The intermetallic phases $\mathrm{S}-\mathrm{Al}_{2} \mathrm{CuMg}$ (fig. 7) and $\alpha-\mathrm{Al}_{2} \mathrm{CuMg}$ (fig. 8) as well as hardening phase $\theta^{\prime}-\mathrm{Al}_{2} \mathrm{Cu}$ (fig. 9-11) were identified in the alloy microstructure by electron diffraction analysis (Pearson, 1967).
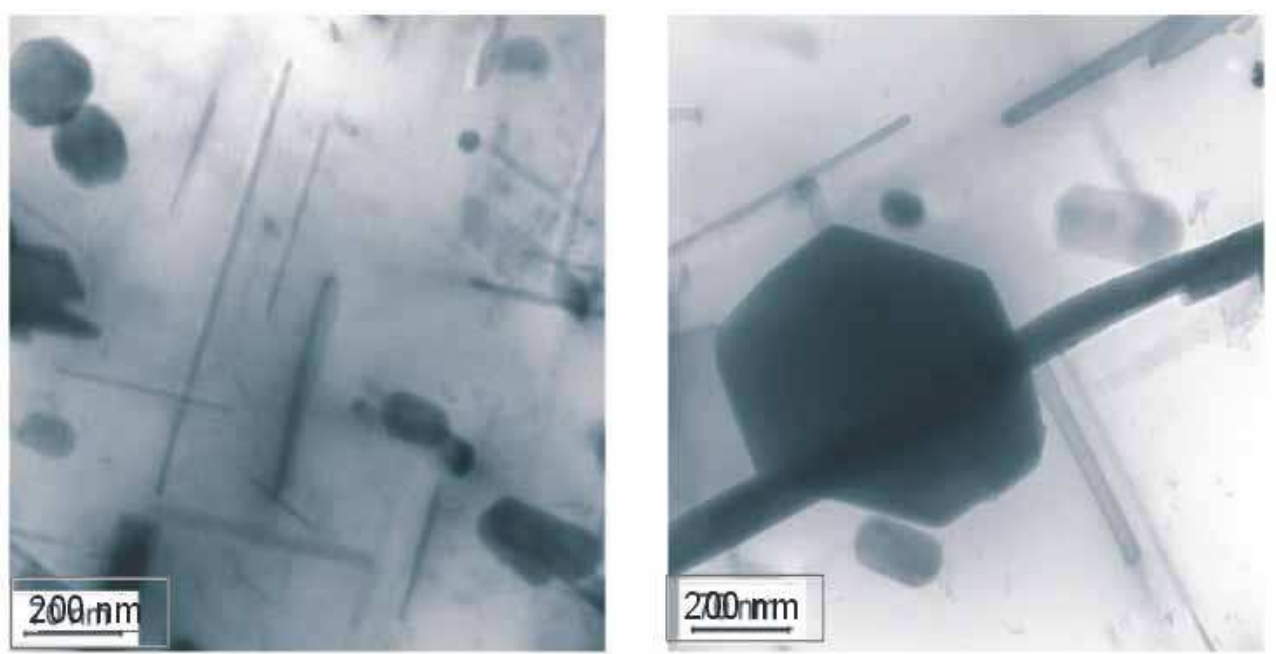

Fig. 9. Microstructure of the AlCu4Ni2Mg alloy in T6 condition (TEM - thin foil). The precipitates of hardening phase $\theta^{\prime}-\mathrm{Al}_{2} \mathrm{Cu}$
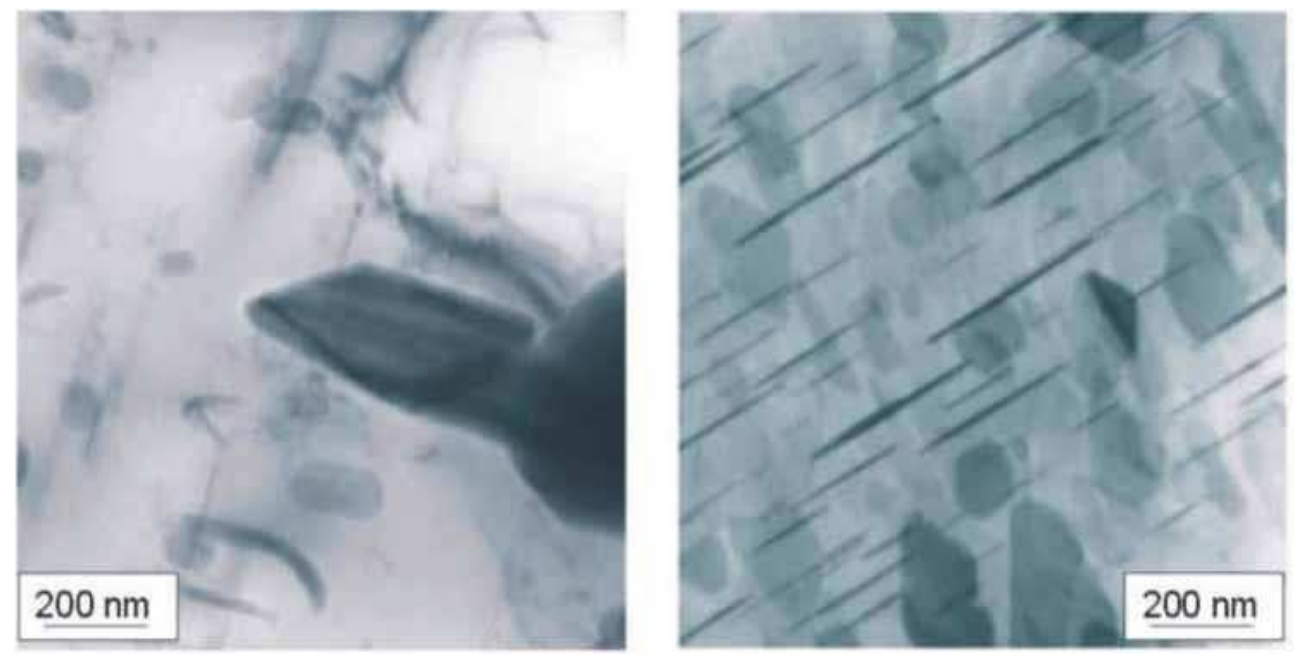

Fig. 10. Microstructure of the AlCu6Ni alloy in T6 condition (TEM - thin foil). The precipitates of hardening phase $\theta^{\prime}-\mathrm{Al}_{2} \mathrm{Cu}$ 
The shape of $\mathrm{Al}_{2} \mathrm{Cu}$ particles was diversified from nearly regular polygons - „crystallites" to strongly elongated - "rod-shaped" (fig. 11-12).
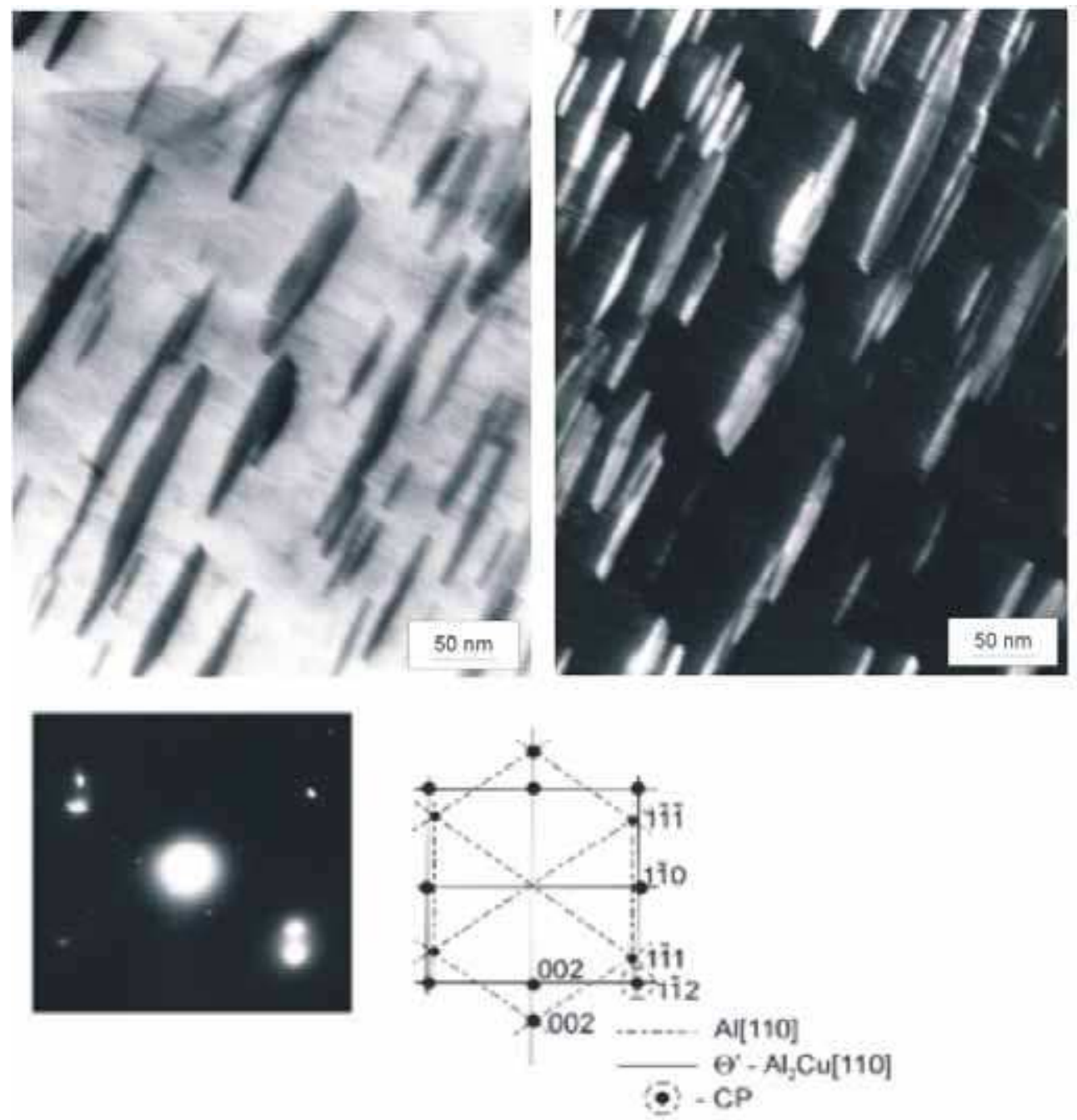

Fig. 11. Microstructure of the AlCu6Ni alloy - precipitates of $\theta^{\prime}-\mathrm{Al}_{2} \mathrm{Cu}$ phase in the shape of plates (TEM - thin foil) 

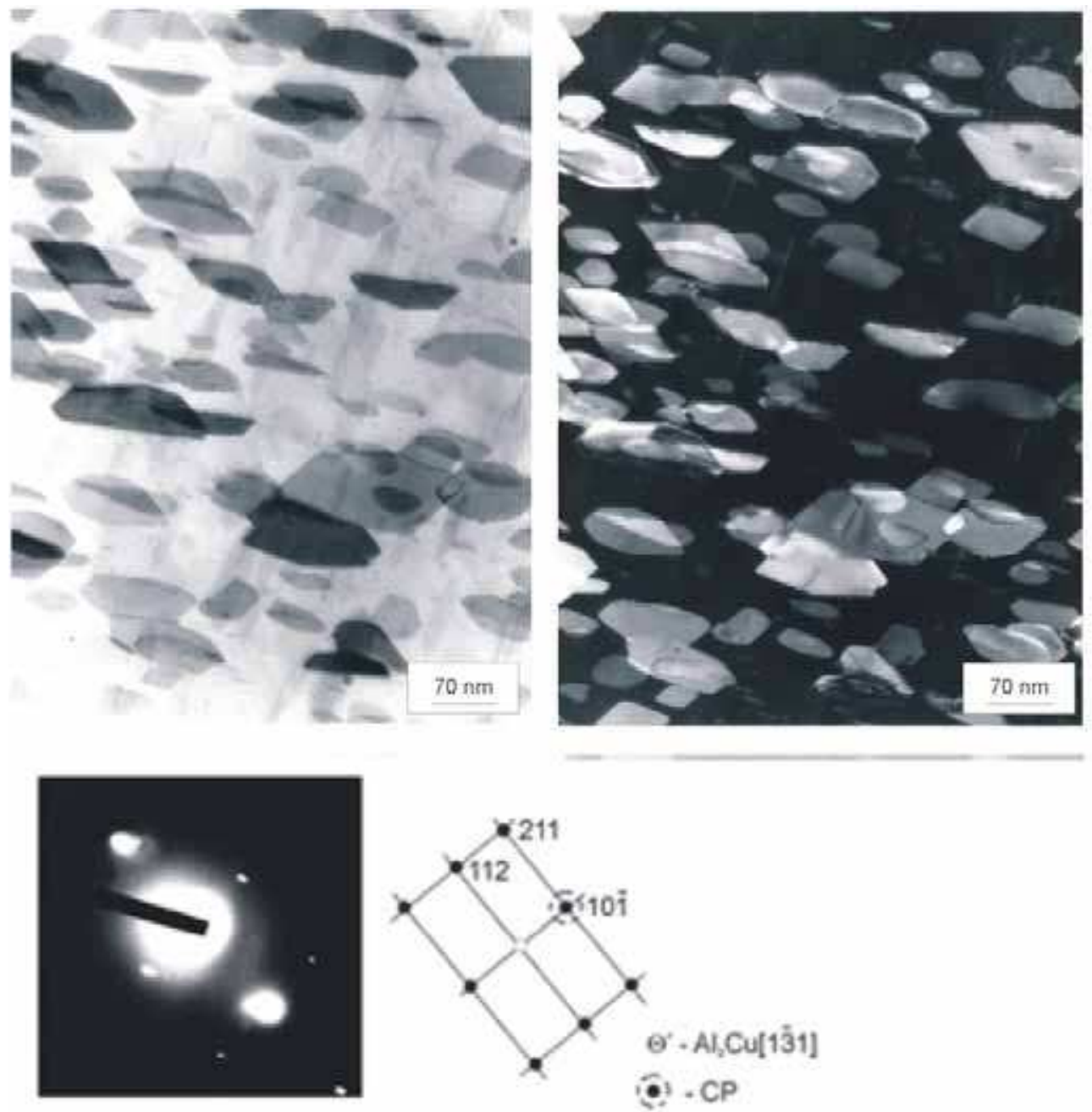

Fig. 12. Microstructure of the $\mathrm{AlCu} 6 \mathrm{Ni}$ alloy - precipitates of $\theta^{\prime}-\mathrm{Al}_{2} \mathrm{Cu}$ phase in the shape of crystallites (TEM - thin foil) 
Examination of the alloys microstructure after prolonged annealing revealed that the precipitates of $\mathrm{Al}_{6} \mathrm{Fe}$ and $\mathrm{S}-\mathrm{Al}_{2} \mathrm{CuMg}$ phases and large precipitates of intermetallic phases at the dendrite boundaries practically did not change (fig. 13-14) even after very long time of annealing (750h). Whereas, significant increase in size of dispersive particles of $\theta^{\prime}-\mathrm{Al}_{2} \mathrm{Cu}$ hardening phase was observed (fig. 15-18).
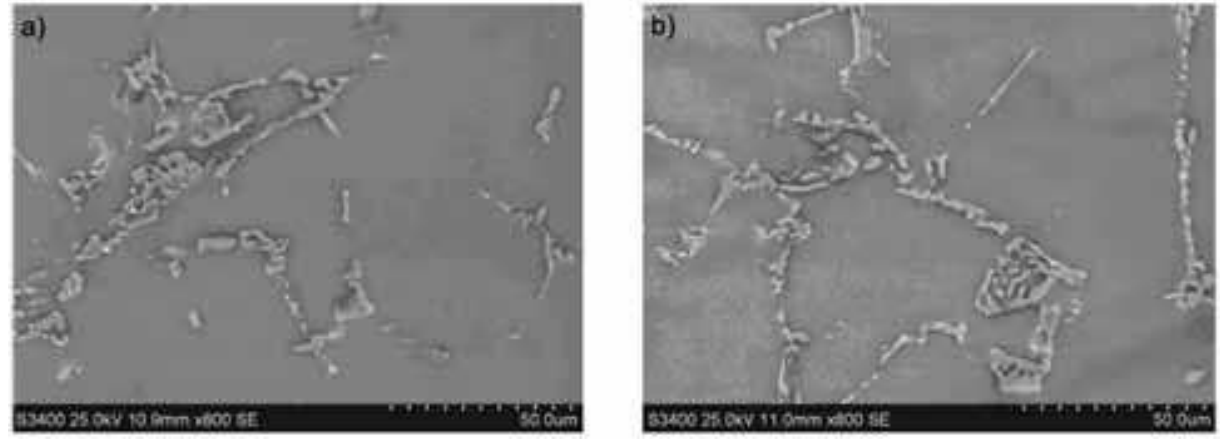

Fig. 13. Microstructure of the AlCu4Ni2Mg alloy after annealing: a) 523K/100h, b) 573K/750h
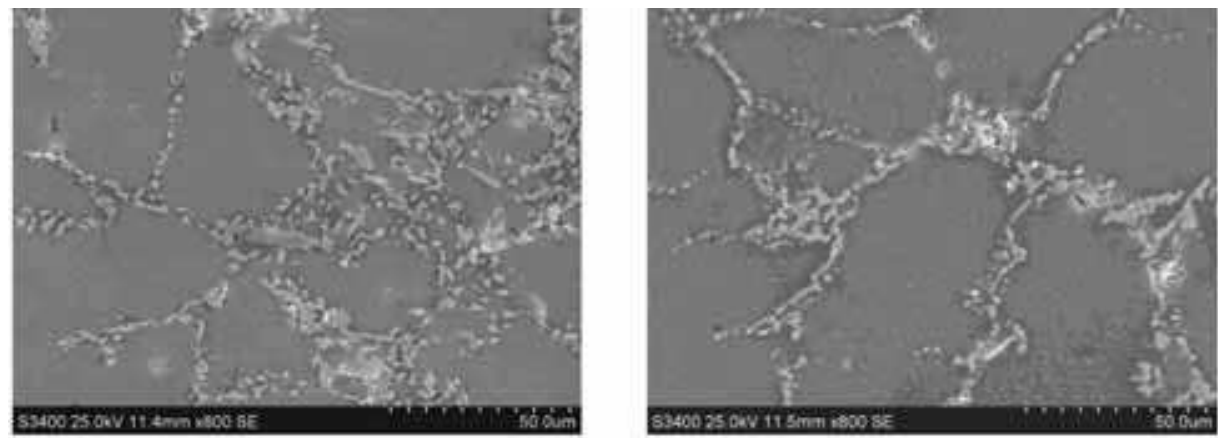

Fig. 14. Microstructure of the AlCu6Ni1 alloy after annealing: a) 523K/100h, b) 573K/750h
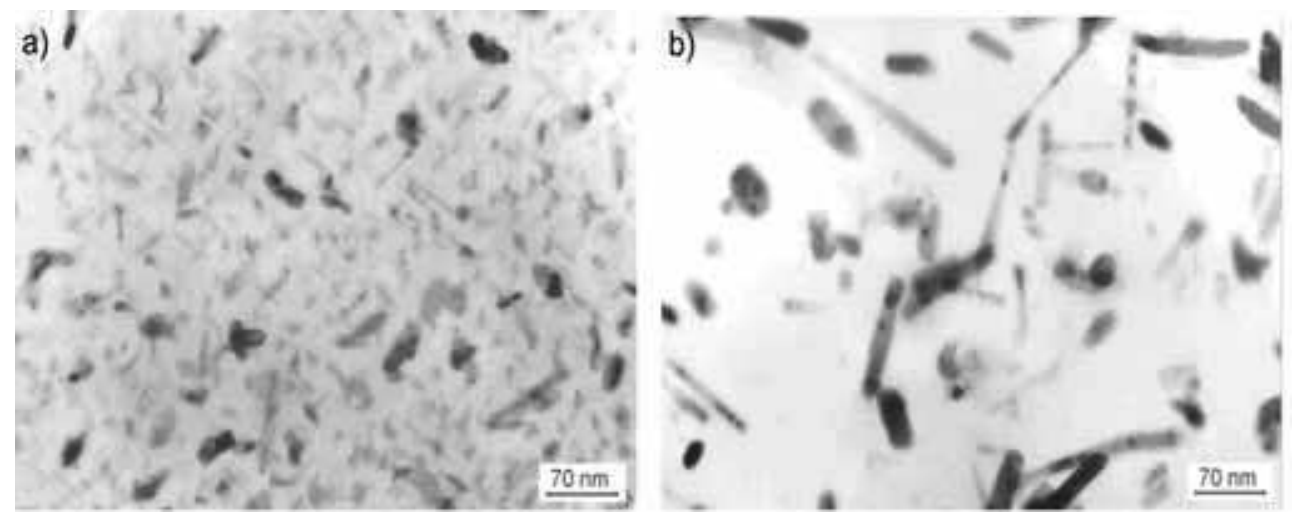

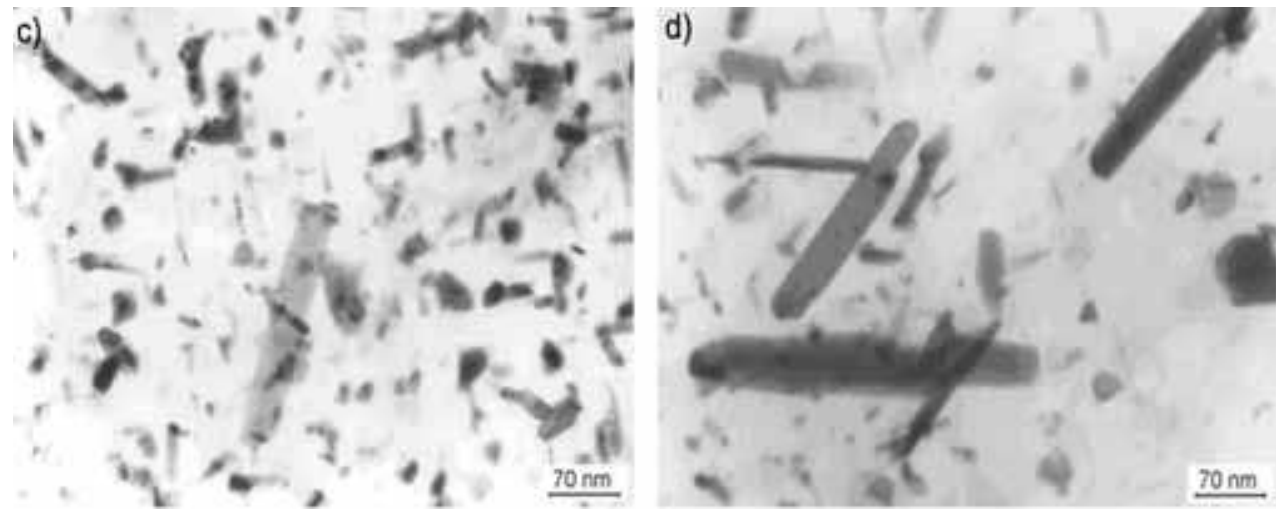

Fig. 15. Microstructure of the $\mathrm{AlCu} 4 \mathrm{Ni} 2 \mathrm{Mg}$ alloy - precipitates of the $\theta^{\prime}-\mathrm{Al}_{2} \mathrm{Cu}$ phase after annealing at $523 \mathrm{~K}$ for: a) $100 \mathrm{~h}, \mathrm{~b}) 300 \mathrm{~h}, \mathrm{c}) 500 \mathrm{~h}$, d) $750 \mathrm{~h}$
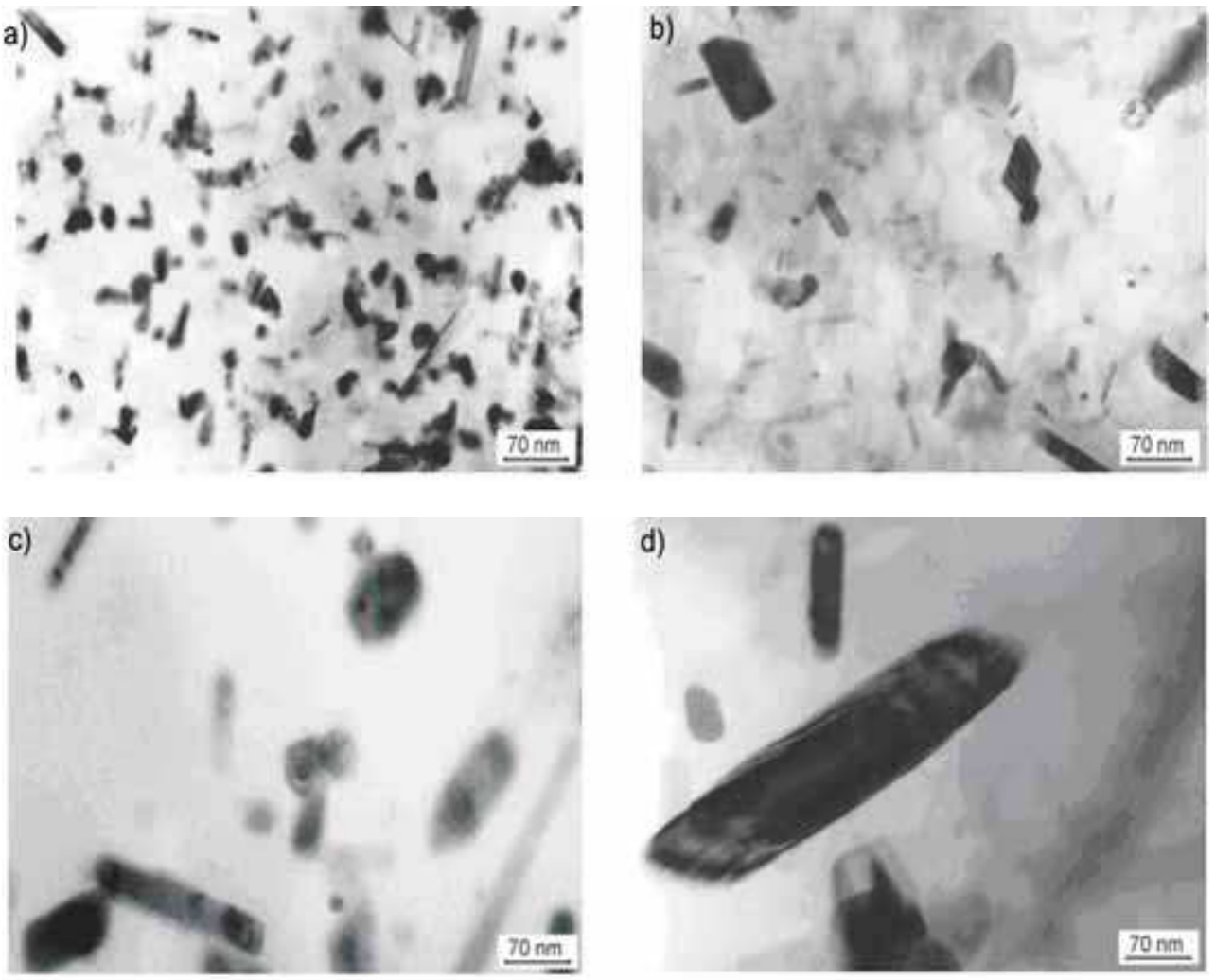

Fig. 16. Microstructure of the $\mathrm{AlCu} 4 \mathrm{Ni} 2 \mathrm{Mg}$ alloy - precipitates of the $\theta^{\prime}-\mathrm{Al}_{2} \mathrm{Cu}$ phase after annealing at 573K for: a) $100 \mathrm{~h}, \mathrm{~b}) 300 \mathrm{~h}, \mathrm{c}) 500 \mathrm{~h}, \mathrm{~d}) 750 \mathrm{~h}$ 

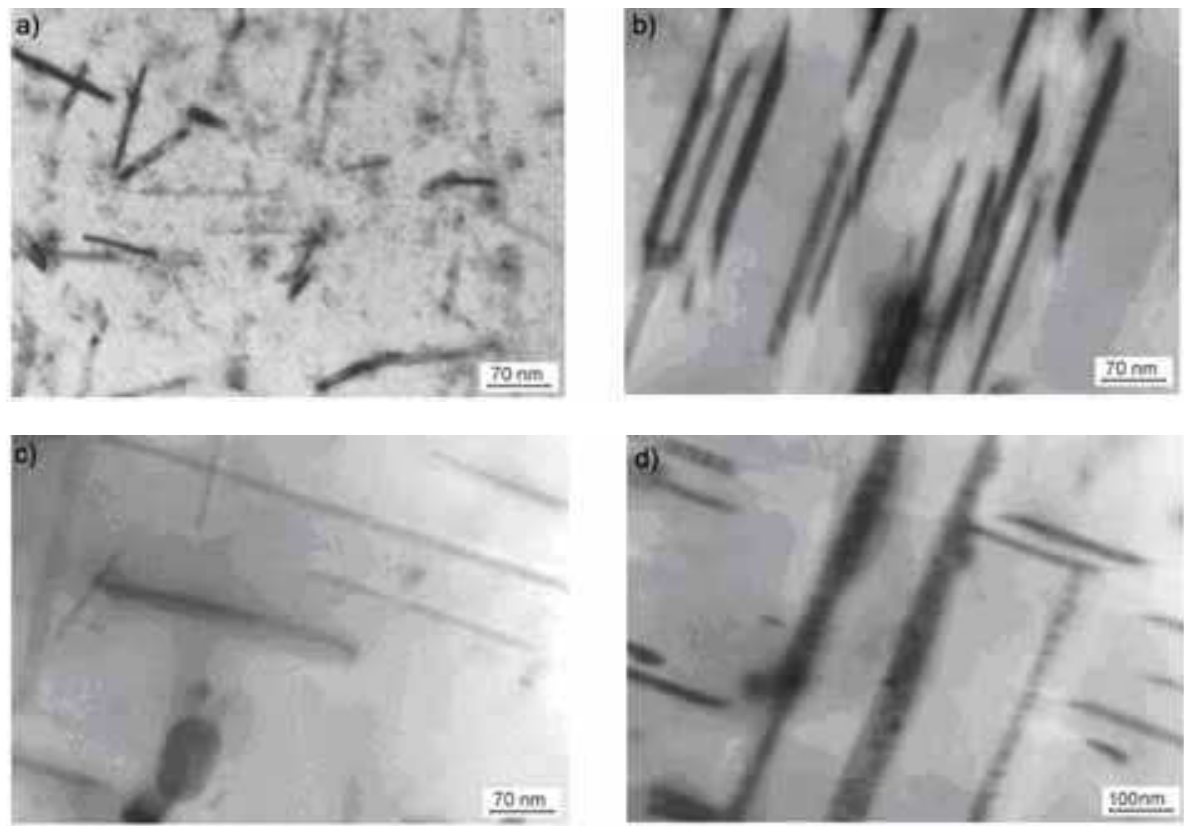

Fig. 17. Microstructure of the $\mathrm{AlCu} 6 \mathrm{Ni}$ alloy - precipitates of the $\theta^{\prime}-\mathrm{Al}_{2} \mathrm{Cu}$ phase after annealing at $523 \mathrm{~K}$ for: a) $100 \mathrm{~h}, \mathrm{~b}) 300 \mathrm{~h}, \mathrm{c}) 500 \mathrm{~h}, \mathrm{~d}) 750 \mathrm{~h}$
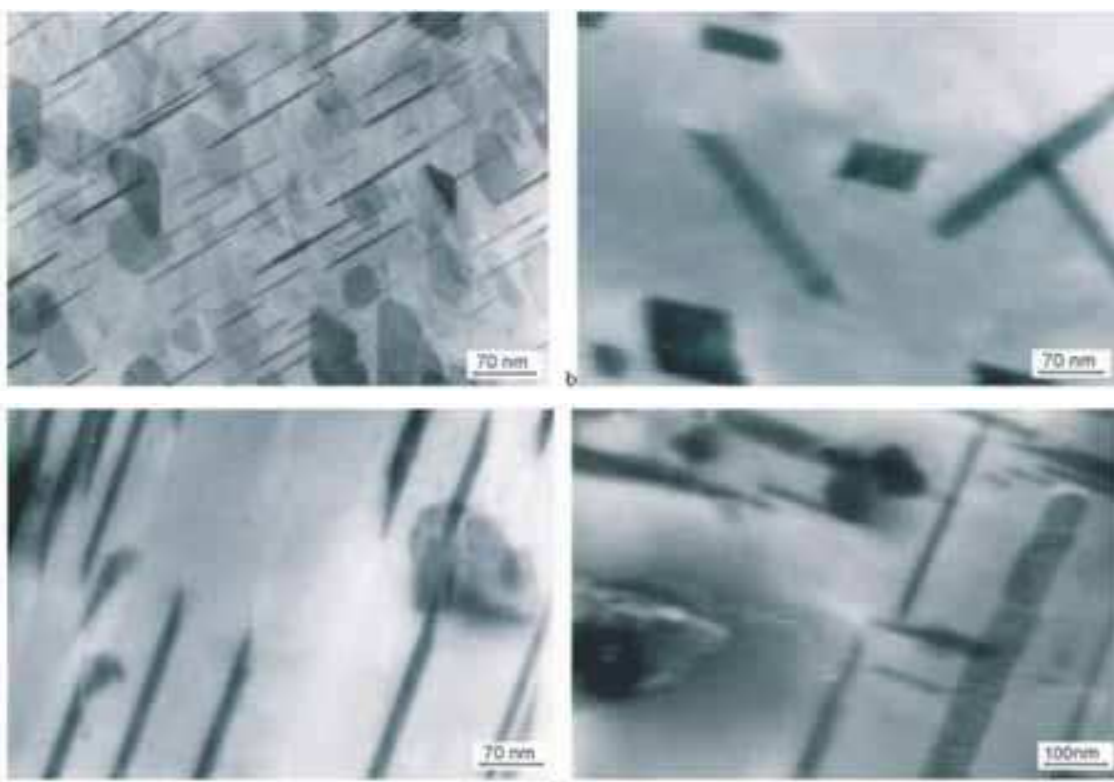

Fig. 18. Microstructure of the $\mathrm{AlCu} \mathrm{Ni}$ - precipitates of the $\theta^{\prime}-\mathrm{Al}_{2} \mathrm{Cu}$ phase after annealing at 573K for: a) $100 \mathrm{~h}, \mathrm{~b}) 300 \mathrm{~h}, \mathrm{c}) 500 \mathrm{~h}, \mathrm{~d}) 750 \mathrm{~h}$ 
Microstructure examination revealed that in both alloys i.e. $\mathrm{AlCu} 4 \mathrm{Ni} 2 \mathrm{Mg}$ and $\mathrm{AlCu} 6 \mathrm{Ni}$ growth of the hardening phase precipitates occured as a result of long-term thermal loading, which was proportional to the temperature and time of annealing. However higher coarsening propensity was found for $\mathrm{Al} 6 \mathrm{CuNi}$ alloy which arose from higher content of the element forming hardening phase $(6 \% \mathrm{Cu})$. It was confirmed by analysis of the change of shape and size of the $\theta^{\prime}-\mathrm{Al}_{2} \mathrm{Cu}$ precipitates in both alloys after annealing at $573 \mathrm{~K}$ for 150 and $750 \mathrm{~h}$ comparing to the standard T6 condition (table 2).

\begin{tabular}{|c|c|c|c|c|}
\hline \multirow{3}{*}{ Alloy } & Shape parameters of & \multicolumn{3}{|c|}{ Heat treatment conditions } \\
\cline { 3 - 5 } & $\theta^{\prime}$-Al ${ }_{2}$ Cu precipitates & \multirow{2}{*}{$\mathrm{T} 6$} & $\mathrm{~T} 6+$ annealing at $573 \mathrm{~K}$ \\
\cline { 3 - 5 } & & & $150 \mathrm{~h}$ & $750 \mathrm{~h}$ \\
\hline \multirow{3}{*}{ AlCu4Ni2Mg } & length, l (nm) & 75,12 & 650,28 & 887,45 \\
\cline { 2 - 5 } & width, w (nm) & 25,20 & 131,15 & 158,19 \\
\cline { 2 - 5 } & shape factor l/w & 2,98 & 4,95 & 5,61 \\
\hline \multirow{3}{*}{ AlCu6Ni } & length, l (nm) & 55,82 & 4465,60 & 6255,05 \\
\cline { 2 - 5 } & width, w (nm) & 10,30 & 115,36 & 149,11 \\
\cline { 2 - 5 } & shape factor, l/w & 5,42 & 38,71 & 41,95 \\
\hline
\end{tabular}

Table 2. Evolution of $\theta^{\prime}-\mathrm{Al}_{2} \mathrm{Cu}$ precipitates in $\mathrm{AlCu} 4 \mathrm{Ni} 2 \mathrm{Mg}$ i $\mathrm{AlCu} 6 \mathrm{Ni}$ alloys during annealing at $573 \mathrm{~K}$ for 150 and $750 \mathrm{~h}$

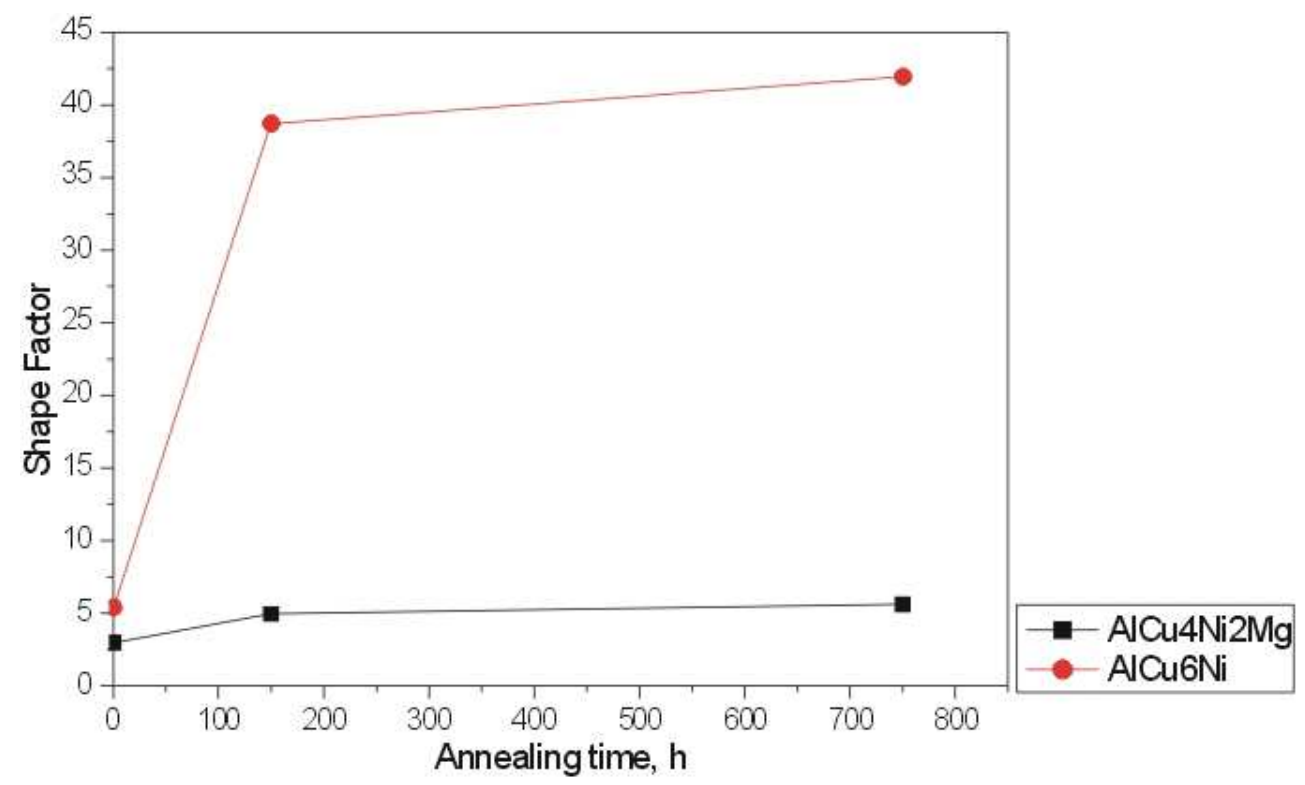

Fig. 19. Change of shape factor of the $\theta^{\prime}-\mathrm{Al}_{2} \mathrm{Cu}$ precipitates in $\mathrm{AlCu} 4 \mathrm{Ni} 2 \mathrm{Mg}$ and $\mathrm{AlCu} 6 \mathrm{Ni}$ as a result of annealing at $573 \mathrm{~K}$ for 150 and $750 \mathrm{~h}$ 
Results of the measurements showed that annealing of the alloys studied at $573 \mathrm{~K}$ led to significant growth of hardening $\theta^{\prime}-\mathrm{Al}_{2} \mathrm{Cu}$ phase precipitates already after $150 \mathrm{~h}$. The biggest change both of size and shape factor of the particles (sevenfold increase) was observed in AlCu6Ni alloy. In the AlCu4Ni2Mg alloy precipitates growth was not so substantial - shape factor was only doubled. Increase in annealing time (750h) resulted in further growth of precipitates. However the process was not so dynamic as in the initial stages of annealing (table 2, fig. 19) - only minor changes of shape factor were observed.

Microstructure examination indicated that growth of the hardening phase precipitates is the main symptom of the microstructure degradation caused by long-term thermal loads. Coarsening and change of the shape of hardening phase particles lead to change of mechanism of their interactions with dislocations and as a consequence of that decrease of strength properties of the alloys (Hirth \& Lothe, 1968).

Results of the static tensile test for the alloys studied in T6 condition and after additional annealing at 523 and $573 \mathrm{~K}$ for 100, 150, 300, 500 and $750 \mathrm{~h}$ are presented in table 3 and in figures 20 and 21.

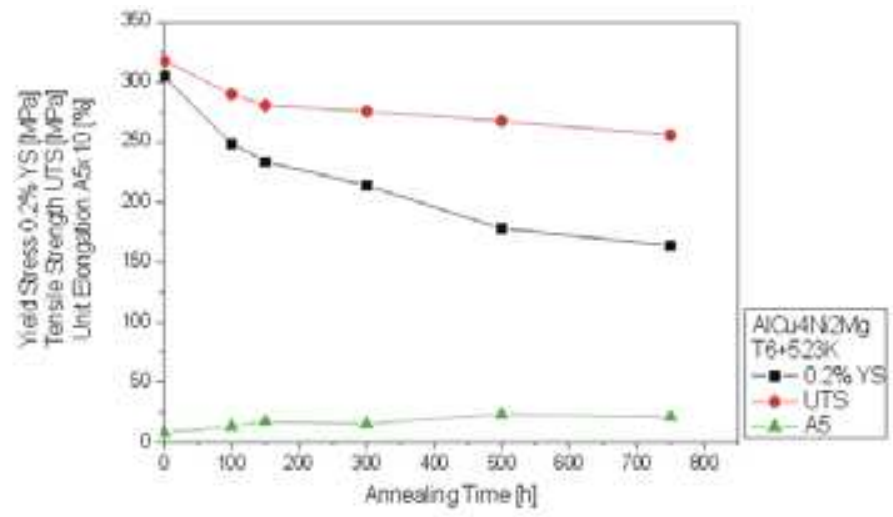

(a)

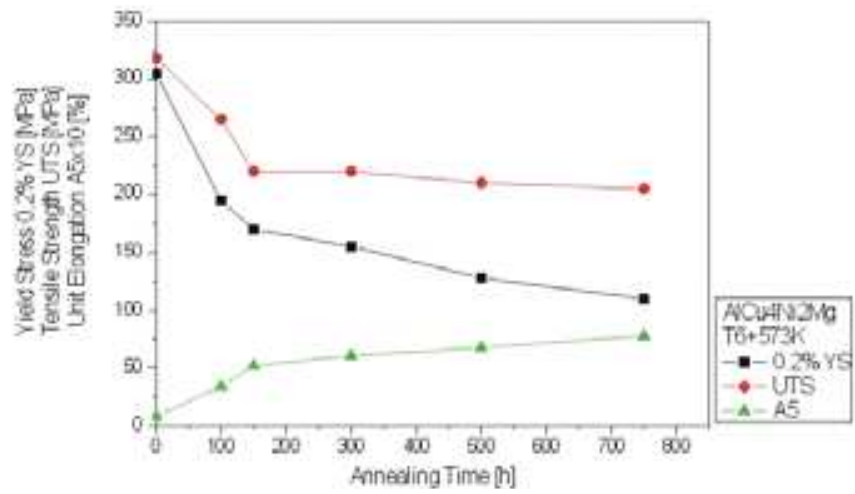

(b)

Fig. 20. Ultimate tensile strength, $0.2 \%$ offset yield strength and elongation $A_{5}$ for $\mathrm{AlCu} 4 \mathrm{Ni} 2 \mathrm{Mg}$ alloy as a function of annealing time at the temperature of a) $523 \mathrm{~K}$ and b) $573 \mathrm{~K}$ 


\begin{tabular}{|c|c|c|c|c|c|c|c|c|c|c|c|c|}
\hline \multirow{2}{*}{$\begin{array}{c}\text { Mechanical } \\
\text { properties }\end{array}$} & \multirow{8}{|c|}{ Heat treatment - temperature and time of annealing } \\
\cline { 2 - 12 } & T6 & $100 \mathrm{~h}$ & $150 \mathrm{~h}$ & $300 \mathrm{~h}$ & $500 \mathrm{~h}$ & $750 \mathrm{~h}$ & $100 \mathrm{~h}$ & $150 \mathrm{~h}$ & $300 \mathrm{~h}$ & $500 \mathrm{~h}$ & $750 \mathrm{~h}$ \\
\hline \multicolumn{10}{|c|}{ AlCu4Ni2Mg alloy } \\
\hline $0.2 \% \mathrm{YS}, \mathrm{MPa}$ & 305 & 249 & 234 & 214 & 178 & 164 & 195 & 170 & 155 & 128 & 110 \\
\hline $\mathrm{UTS}, \mathrm{MPa}$ & 318 & 290 & 281 & 276 & 268 & 256 & 265 & 220 & 220 & 210 & 205 \\
\hline $\mathrm{A}_{5} \%$ & 0,8 & 1,3 & 1,7 & 1,5 & 2,3 & 2,1 & 3,4 & 5,2 & 6,1 & 6,8 & 7,8 \\
\hline \multicolumn{10}{|c|}{ AlCu6Ni alloy } \\
\hline $0.2 \% \mathrm{YS}, \mathrm{MPa}$ & 285 & 225 & 215 & 185 & 168 & 142 & 180 & 147 & 140 & 118 & 104 \\
\hline UTS, MPa & 323 & 305 & 290 & 277 & 263 & 243 & 245 & 240 & 216 & 192 & 177 \\
\hline $\mathrm{A}_{5} \%$ & 0,7 & 1,3 & 1,9 & 2,6 & 3,1 & 3,8 & 2,4 & 4,2 & 5,6 & 6,8 & 7,0 \\
\hline
\end{tabular}

Table 3. Mechanical properties of the AlCu4Ni2Mg and AlCu6Ni alloys in standard T6 condition and after additional annealing at 523 and $573 \mathrm{~K}$

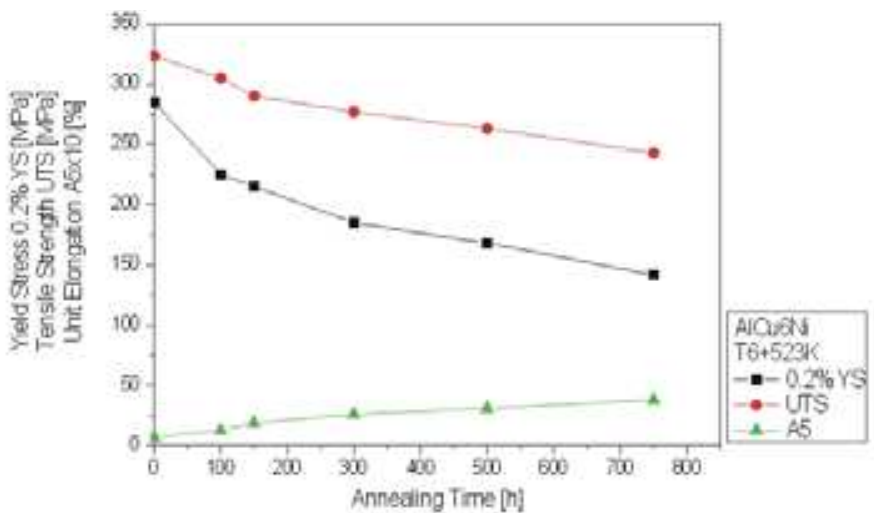

(a)

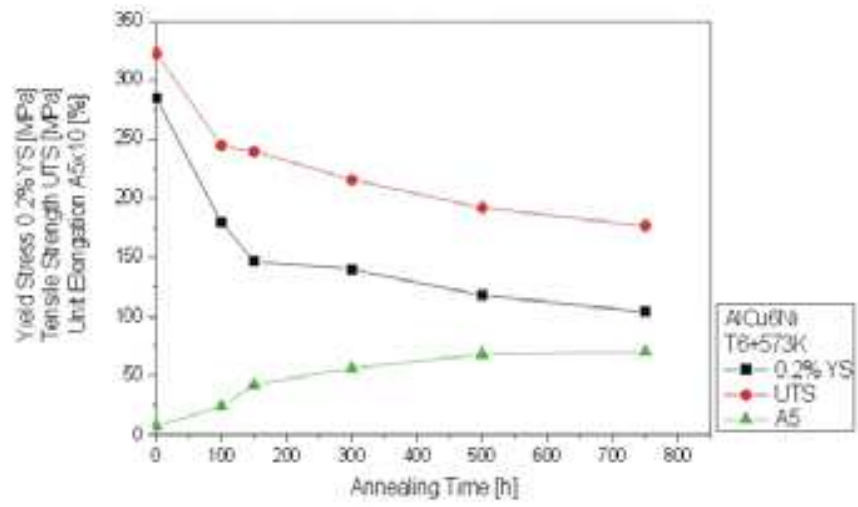

(b)

Fig. 21. Ultimate tensile strength, $0.2 \%$ offset yield strength and elongation $\mathrm{A}_{5}$ for $\mathrm{AlCu} 6 \mathrm{Ni}$ alloy as a function of annealing time at the temperature of a) $523 \mathrm{~K}$ and b) $573 \mathrm{~K}$ 


\begin{tabular}{|c|c|c|c|c|c|c|c|c|c|c|}
\hline \multirow{2}{*}{$\begin{array}{c}\text { Annealing } \\
\text { temperature }\end{array}$} & \multicolumn{5}{|c|}{$\left[\left(\mathrm{UTS}^{-U_{T S}}(\mathrm{~T})\right) / \mathrm{UTS}\right] \times 100 \%$} & \multicolumn{5}{|c|}{$\left[\left(\mathrm{YS}_{\mathrm{S}} \mathrm{YS}_{(\mathrm{T})}\right) / \mathrm{YS}\right] \times 100 \%$} \\
\hline & $100 \mathrm{~h}$ & $150 \mathrm{~h}$ & $300 \mathrm{~h}$ & $500 \mathrm{~h}$ & $750 \mathrm{~h}$ & $100 \mathrm{~h}$ & $150 \mathrm{~h}$ & $300 \mathrm{~h}$ & $500 \mathrm{~h}$ & $750 \mathrm{~h}$ \\
\hline & \multicolumn{10}{|c|}{$\mathrm{AlCu} 4 \mathrm{Ni} 2 \mathrm{Mg}$} \\
\hline $523 \mathrm{~K}$ & 9 & 12 & 13 & 16 & 19 & 18 & 23 & 30 & 42 & 46 \\
\hline \multirow[t]{2}{*}{$573 \mathrm{~K}$} & 17 & 31 & 31 & 34 & 35 & 36 & 44 & 49 & 58 & 64 \\
\hline & \multicolumn{10}{|c|}{ AlCu6Ni } \\
\hline $523 \mathrm{~K}$ & 5 & 10 & 14 & 19 & 24 & 21 & 25 & 35 & 41 & 50 \\
\hline $573 \mathrm{~K}$ & 24 & 26 & 33 & 40 & 45 & 37 & 48 & 51 & 59 & 64 \\
\hline
\end{tabular}

Table 4. Relative decrease of ultimate tensile strength and $0.2 \%$ offset yield strength of the $\mathrm{AlCu} 4 \mathrm{Ni} 2 \mathrm{Mg}$ and $\mathrm{AlCu} 6 \mathrm{Ni1}$ alloys after annealing at 523 and $573 \mathrm{~K}$

It was found that both alloys subjected to long-term annealing exhibit significant reduction of mechanical properties. This tendency was characterized by the coefficient calculated according to the formula $\left[\left(\mathrm{R}-\mathrm{R}_{(\mathrm{T})}\right) \times \mathrm{R}^{-1} \times 100 \%\right]$ where: $\mathrm{R}-\mathrm{UTS}$ or YS in T6 condition, $\mathrm{R}_{(\mathrm{T})}-$ UTS or YS after annealing at 523/573K (table 4). The analysis of the dependence of that

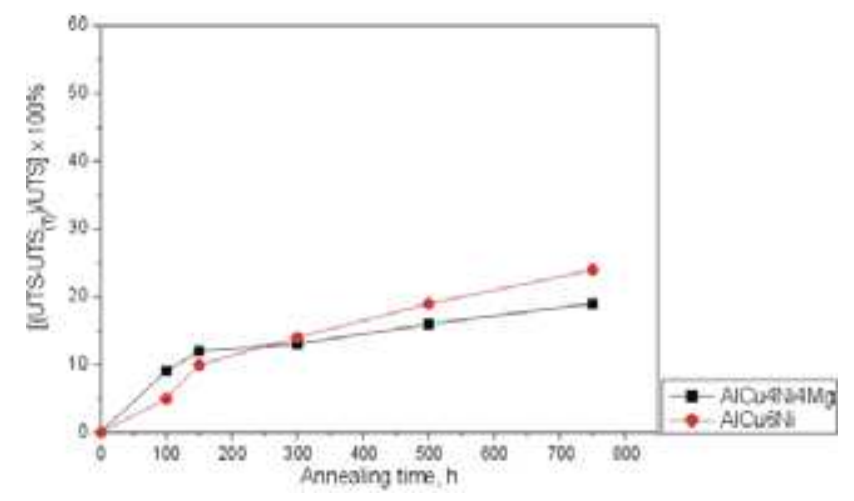

(a)

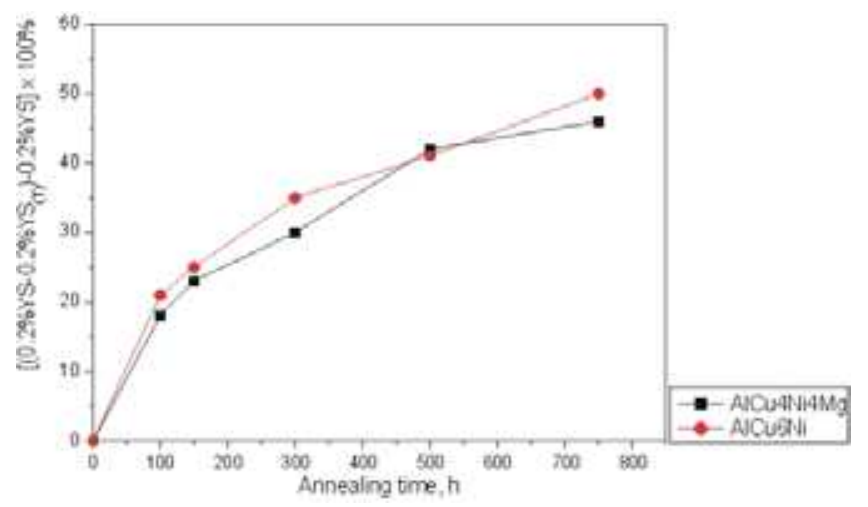

(b)

Fig. 22. Relative change of ultimate tensile strength (a) and $0.2 \%$ offset yield strength (b) of the $\mathrm{AlCu} 4 \mathrm{Ni} 2 \mathrm{Mg}$ and $\mathrm{AlCu} 6 \mathrm{Ni}$ alloys as a function of time of annealing at 523 
coefficient value on time of annealing enabled comparison of stability of mechanical properties of the investigated alloys (fig. 22 and 23).

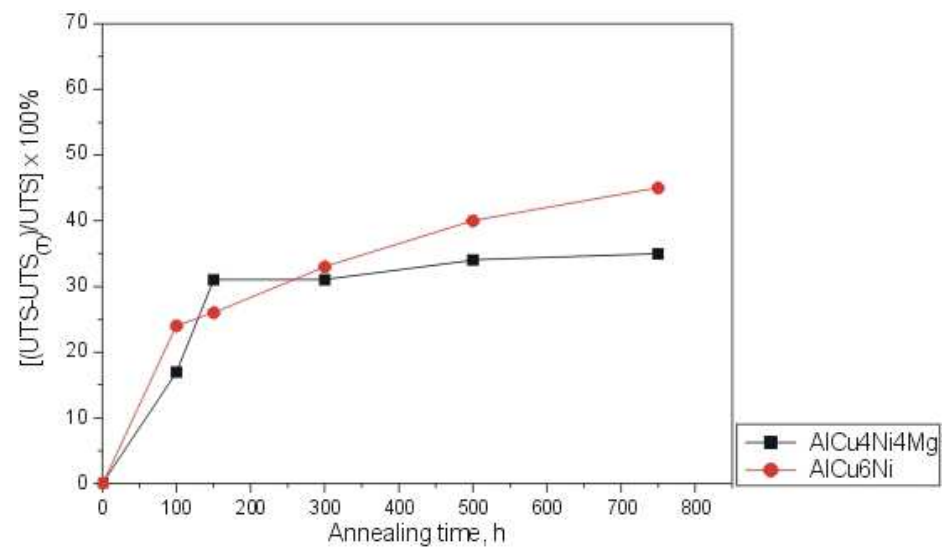

(a)

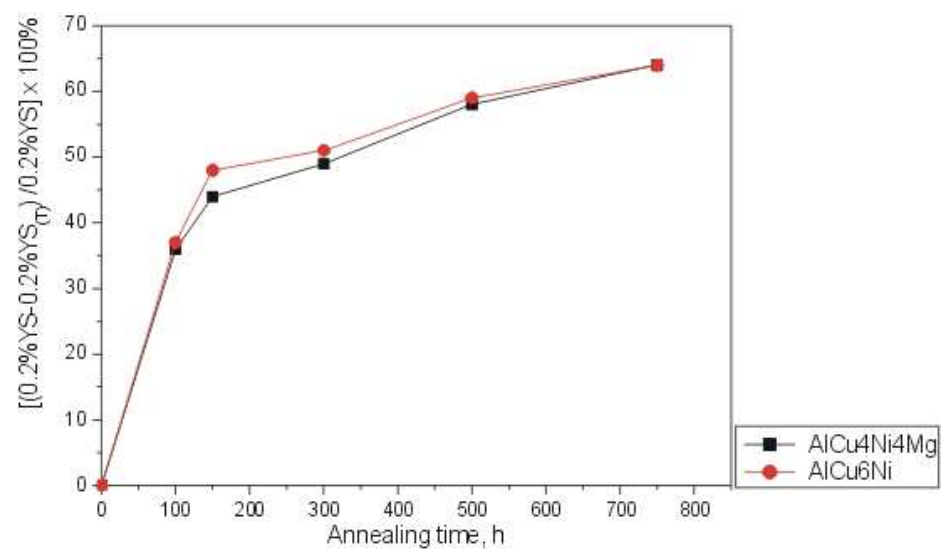

(b)

Fig. 23. Relative change of ultimate tensile strength (a) and $0.2 \%$ offset yield strength (b) of the $\mathrm{AlCu} 4 \mathrm{Ni} 2 \mathrm{Mg}$ and $\mathrm{AlCu} 6 \mathrm{Ni}$ alloys as a function of time of annealing at $573 \mathrm{~K}$

Repeatability of the mechanical properties of $\mathrm{AlCu} 4 \mathrm{Ni} 2 \mathrm{Mg}$ and $\mathrm{AlCu} 6 \mathrm{Ni}$ alloys after longterm annealing was determined on the basis of variation of the static tensile test results (table 5). Five specimens were tested for each temperature and time of annealing. Coefficient of variation was calculated using formula:

$$
W_{z}=\frac{s}{\bar{x}} \times 100
$$

where: $s$ - standard deviation, $\bar{x}$ - average value 
Values of the ultimate tensile strength and $0.2 \%$ offset yield strength of the alloy subjected to long-term thermal loads $(573 \mathrm{~K} / 750 \mathrm{~h})$ characterize its ability to preserve strength properties in operation condition of the castings (table 5).

\begin{tabular}{|c|c|c|c|c|}
\hline \multirow{2}{*}{$\begin{array}{c}\text { Annealing } \\
\text { temperature, } \\
\mathrm{K}\end{array}$} & Alloy & \multicolumn{2}{|c|}{$0.2 \%$ offset yield strength } & \multirow{2}{*}{$\mathrm{W}_{\mathrm{z}} \%$} \\
\cline { 3 - 4 } & & $\begin{array}{c}Y S_{(\max )}, \mathrm{MPa} \\
\text { in T6 condition }\end{array}$ & $\begin{array}{c}Y S_{(\min )}, \mathrm{MPa} \\
\text { after annealing for } 750 \mathrm{~h}\end{array}$ & \\
\hline 523 & $\mathrm{AlCu} 4 \mathrm{Ni} 2 \mathrm{Mg}$ & 305 & 164 & 18 \\
\cline { 2 - 5 } & $\mathrm{AlCu} 6 \mathrm{Ni}$ & 285 & 142 & 11 \\
\hline 573 & $\mathrm{AlCu} 4 \mathrm{Ni} 2 \mathrm{Mg}$ & 305 & 110 & 25 \\
\cline { 2 - 5 } & $\mathrm{AlCu} 6 \mathrm{Ni}$ & 285 & 104 & 18 \\
\hline
\end{tabular}

Table 5. Minimum values of the $0.2 \%$ offset yield strength of the $\mathrm{AlCu} 4 \mathrm{Ni} 2 \mathrm{Mg}$ and $\mathrm{AlCu} 6 \mathrm{Ni}$ alloys after annealing at 523/573K for $750 \mathrm{~h}$ and maximum values obtained for T6 condition

Both alloys exhibit similar repeatability of tensile test results, however AlCu6Ni alloy shows slightly better stability of strength properties (table 5). However AlCu4Ni2Mg alloy is superior to $\mathrm{AlCu} 6 \mathrm{Ni}$ alloy in terms of maximum and minimum yield strength after particular heat treatment. It has also higher ultimate tensile strength.

\section{Conclusions}

In the $\mathrm{AlCu} 4 \mathrm{Ni} 2 \mathrm{Mg}$ and $\mathrm{AlCu} 6 \mathrm{Ni}$ alloys degradation of the microstructure takes place as a result of long-term thermal loading. It consists largely in coarsening and the change of the shape of hardening phase particles $\left(\theta^{\prime}-\mathrm{Al}_{2} \mathrm{Cu}\right)$. The changes are proportional to the annealing time and temperature and lead to significant decrease of the mechanical properties of the alloys. The alloys studied are characterized by different content of $\mathrm{Cu}$ - primary element forming hardening phase. Increased $\mathrm{Cu}$ content in $\mathrm{AlCu} 6 \mathrm{Ni}$ alloy caused only slight improvement of the stability of its strength properties. The $\mathrm{AlCu} 4 \mathrm{Ni} 2 \mathrm{Mg}$ alloy containing less $\mathrm{Cu}$ but with addition of $\mathrm{Mg}$ is characterized by better strength properties than AlCu6Ni alloy in T6 condition and preserves relatively high tensile strength and good ductility after long-term thermal loading. Taking into account criterion of mechanical properties and their stability both alloys studied can be successfully applied for highly stressed elements of aircraft structures operating in the temperature range of $523-573 \mathrm{~K}$.

\section{References}

El-Magd, E. \& Dünnwald, J. (1996). Influence of constitution on the high-temperature creep behavior of AlCuMg alloy. Metallkunde, Vol.506, pp.411-414

Hirth, J.P. \& Lothe, J. (1968). Theory of dislocations. McGraw-Hill, New York-London Martin, J.W. Preciptation Hardening. (1968). Pergamon Press, Oxford

Mrówka-Nowotnik, G., Wierzbińska, M., \& Sieniawski J. Analysis of intermetallic particles in AlSi1MgMn aluminium alloy. (2007). eburnal of Archieves in Materials and Manufacturing Engineering, Vol.1-2, No.20, pp.155-158 
Person, W.B. (1997). A Handbook of Lattice Spacing and Structures of Metals and Alloys, Vol.2, Pergamon Press, Oxford-London-Edinburgh-New York-Toronto-SydneyParis-Braunschweig

Wierzbińska, M. \& Sieniawski, J. (2010). Microstructural changes to AlCu6Ni1 alliy after prolonged annealing at elevated temperature. eburnal of Microscopy, Vol.237, No.3, pp.516-520 


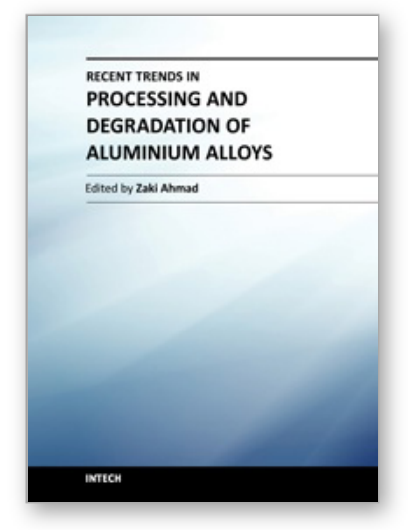

\section{Recent Trends in Processing and Degradation of Aluminium Alloys \\ Edited by Prof. Zaki Ahmad}

ISBN 978-953-307-734-5

Hard cover, 516 pages

Publisher InTech

Published online 21, November, 2011

Published in print edition November, 2011

In the recent decade a quantum leap has been made in production of aluminum alloys and new techniques of casting, forming, welding and surface modification have been evolved to improve the structural integrity of aluminum alloys. This book covers the essential need for the industrial and academic communities for update information. It would also be useful for entrepreneurs technocrats and all those interested in the production and the application of aluminum alloys and strategic structures. It would also help the instructors at senior and graduate level to support their text.

\section{How to reference}

In order to correctly reference this scholarly work, feel free to copy and paste the following:

Malgorzata Wierzbinska and Jan Sieniawski (2011). Microstructural Changes of Al-Cu Alloys After Prolonged Annealing at Elevated Temperature, Recent Trends in Processing and Degradation of Aluminium Alloys, Prof. Zaki Ahmad (Ed.), ISBN: 978-953-307-734-5, InTech, Available from:

http://www.intechopen.com/books/recent-trends-in-processing-and-degradation-of-aluminiumalloys/microstructural-changes-of-al-cu-alloys-after-prolonged-annealing-at-elevated-temperature

\section{INTECH}

open science | open minds

\section{InTech Europe}

University Campus STeP Ri Slavka Krautzeka 83/A 51000 Rijeka, Croatia Phone: +385 (51) 770447 Fax: +385 (51) 686166 www.intechopen.com

\section{InTech China}

Unit 405, Office Block, Hotel Equatorial Shanghai No.65, Yan An Road (West), Shanghai, 200040, China 中国上海市延安西路65号上海国际贵都大饭店办公楼405单元 Phone: +86-21-62489820

Fax: $+86-21-62489821$ 
(C) 2011 The Author(s). Licensee IntechOpen. This is an open access article distributed under the terms of the Creative Commons Attribution 3.0 License, which permits unrestricted use, distribution, and reproduction in any medium, provided the original work is properly cited. 